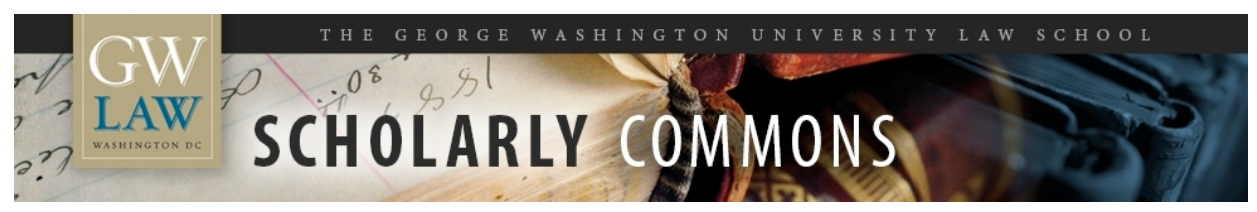

\title{
Problems in Environmental Protection and Human Rights: A Human Right to the Environment
}

Dinah L. Shelton

George Washington University Law School, dshelton@law.gwu.edu

Follow this and additional works at: https://scholarship.law.gwu.edu/faculty_publications

Part of the Law Commons

\section{Recommended Citation}

Shelton, Dinah L., "Problems in Environmental Protection and Human Rights: A Human Right to the Environment" (2011). GW Law Faculty Publications \& Other Works. 1048.

https://scholarship.law.gwu.edu/faculty_publications/1048

This Article is brought to you for free and open access by the Faculty Scholarship at Scholarly Commons. It has been accepted for inclusion in GW Law Faculty Publications \& Other Works by an authorized administrator of Scholarly Commons. For more information, please contact spagel@law.gwu.edu. 


\section{Donald K. Anton \& Dinah SHELton, Environmental Protection and HuMan Rights (Cambridge Univ. Press, 2011)}

\section{A Human Right to a Healthy Environment Case Study}

\section{International Guarantees}

The African Charter on Human and Peoples' Rights, (26 June 1981), Article 24 provides that "All peoples shall have the right to a general satisfactory environment favorable to their development." The Additional Protocol to the American Convention on Human Rights in the area of Economic, Social and Cultural Rights (17 Nov. 1988), Article 11, proclaims:

1. Everyone shall have the right to live in a healthy environment and to have access to basic public services.

2. The States Parties shall promote the protection, preservation and improvement of the environment.

However, the Protocol only permits complaints to be filed alleging violations of the right to education and the right to trade union freedoms. This creates difficulties for invoking Protocol Article 11 directly before the Inter-American institutions.

The African system has few limits on justiciability and provides very broad standing to file complaints. The first decision of the African Commission on Human and Peoples' Rights concerning environmental quality arose from Communications 25/89, 47/90, 56/91 and 100/93 against Zaire, summarized infra. Later, the Commission received the much larger case centering on oil exploration and exploitation in the Niger River Delta. What does it suggest about the content of the right to environment and the corresponding state duties? For commentaries on the case and the Ogoni conflict generally, see Fons Coomans, The Ogoni Case Before the African Commission on Human and Peoples'Rights, 52 INT'L \& COMP. L.Q. 749 (2003); Joshua P. Eaton, The Nigerian Tragedy, Environmental Regulation of Transnational Corporations, and the Human Right to a Healthy Environment, 15 B.U. INT'L L.J. 261, 293 (1997).

\section{National Guarantees of the Right to a Safe and Healthy Environment}

Some 130 constitutions in the world, including the overwhelming proportion of those amended or written since 1970, include a state obligation to protect the environment or a right to a safe, healthy, ecologically-balanced (or other adjective) environment. About half the constitutions take the rightsbased approach and the other half proclaim state duties. This section looks at environmental rights in Europe, the United States, and South Africa.

\section{European Environmental Human Rights and Environmental Rights: A Long Time Coming? Ole Pedersen \\ 21 GEO. INT'L ENVTL.L.REV. 73, 108-111 (2008)(footnotes renumbered)}

Although the approach to a substantive right to the environment is perhaps one of caution on a regional level in Europe, a number of national constitutions recognize rights to a healthy 
environment. These constitutional provisions, while effective only on a national level, indicate that the issue is one of increasing importance throughout Europe. ${ }^{1}$

For instance, the French Constitution was amended in 2005 and now includes a Charter of the Environment ("Charter"). ${ }^{2}$ The Charter affords all citizens of France the right to live in a "balanced environment, favorable to human health." ${ }^{3}$ The Charter has been relied upon by the French Conseil Constitutionnel in reviewing the constitutionality of ordinary bills. For instance, in a case from 2005 dealing with the establishment of a maritime register the Conseil Constitutionnel relied on the Charter although it did not find that the proposed bill violated the Charter's provisions. ${ }^{4}$ The Charter was also relied upon by a local administrative court in 2005 when it suspended the granting of an administrative permission to host a rave party in a former airfield, which had subsequently been listed under domestic nature conservation law. ${ }^{5}$ Here, the court found that the Charter constituted a "fundamental freedom" of constitutional value allowing for the suspension of the administrative permission under French procedural law. ${ }^{6}$

The French amendment serves to increase the number of European constitutions facilitating a human right to the environment. For example: the Constitution of Belgium, where the right to "lead a worthy life of human dignity" includes "the right to protection of a sound environment"; ${ }^{7}$ Portugal where the Constitution asserts that "all have the right to a healthy ecologically balanced human environment and the duty to defend it"; ${ }^{8}$ and Spain where the Constitution states that "everyone has the right to enjoy an environment suitable for the development of the person as well as the duty to preserve it." "Further north, the Finnish Constitution, adopted in 2000, states that the "public

\footnotetext{
1 Apart from providing for a specific right, some constitutions contain general provisions on the environment in the shape of broad policy statements. See, e.g., STATUUT NED [Constitution] ch. I, art. 21 (Neth.), translated in CONSTITUTIONS OF THE COUNTRIES OF THE WORLD (Rüdiger Wolfrum \& Rainer Grote eds., Nov. 2005) (stating "it shall be the concern of the authorities to keep the country habitable and to protect and improve the environment").
}

${ }^{2}$ Legifrance, Charter for the Environment, art. 1, http://www.legifrance.gouv.fr/html/constitution/const03.htm; see, e.g., David Marrani, The Second Anniversary of the Constitutionalisation of the French Charter for the Environment: Constitutional and Environmental Implications, 10 ENV. L. REV. 9 (2008); James R. May, Constituting Fundamental Environmental Rights Worldwide, 23 PACE ENVTL. L. REV. 113, 113-14 (2005-2006).

${ }^{3}$ [Legifrance, Id.]

4 See CC decision no. 2005-514DC, Apr. 28, 2005, R. 305 (Loi relative à la création du registre international français); Marrani, supra note [33].

5 See Marrani, supra note [33], at 21-22.

${ }^{6}$ Id.

7 LA CONSTitution Belge art. 23(3)(4) (Belg.), translated in CONSTITUTIONS OF THE CountRIES OF THE World, supra note [32]; see also Marc Martens, Constitutional Right to a Healthy Environment in Belgium, 16 ReV. EUR. CMTY \& INT'L ENVTL. L. 287 (2007) (noting that the right in Article 23 amounts to a so-called standstill obligation upon the state).

8 Constituição Da República Portuguesa [Constitution] art. 66 (Port.), translated in Constitutions of THE COUNTRIES OF THE WORLD, supra note [32].

9

C.E. [Constitution] art. 45 (Spain), translated in CONSTITUTIONS OF THE COUNTRIES OF THE WorLD, supra note [32]. However, the right enshrined in the Spanish Constitution has been called into question as it has been argued that it serves more as a policy principle. See Ernst Brandl \& Hartwin Bungert, Constitutional Entrenchment of Environmental Protection: A Comparative Analysis of Experiences Abroad, 16 HARV. ENVTL. L. REV. 1, 61-63 (1992); Douglas-Scott, supra note 202, at 110-11. 
authorities shall endeavor to guarantee for everyone the right to a healthy environment." ${ }^{10}$ Likewise, the Norwegian Constitution, altered in 1992, contains a right to "an environment that is conducive to health." 11 In addition, a great number of Eastern European countries have, following the breakdown of the Soviet Union, altered or changed their constitutions to include a substantive right to the environment. $^{12}$

Thus, the vast number of national constitutions holding provisions on substantive as well as procedural environmental rights adds further impetus to the use of rights to provide for environmental protections. As for the substantive norms, the rights in the national constitutions have the potential to influence debates on the status of a substantive environmental norm under international law. Here it is worth recalling Taşkin v. Turkey, where the plaintiff relied on the right to a healthy environment in the Turkish Constitution before the court, which found this to constitute a civil right within the meaning of the ECHR. National constitutional environmental rights are strong indicators of national opinio juris and represent the highest level of national law operating as a lex suprema. In addition, many of the constitutions changed throughout the last twenty years have been amended to specifically accommodate these rights.

\section{A. The United States}

The United States federal constitution is not one of those that mention the environment unsurprising given that the constitution was drafted in 1789 - and rights are not often implied as a result of litigation. Nonetheless, in 1968, the same year the government of Sweden proposed to the United Nations that it convene its first international conference on the human environment, U.S. Senator Gaylord Nelson introduced a draft constitutional amendment that would have recognized in the Bill of Rights that "[e]very person has the inalienable right to a decent environment." H.R. J. Res. $1321,90^{\text {th }}$ Cong., $2 \mathrm{~d}$ Sess. (1968). The proposal failed, as did later attempts to recognize such a right. H.R. J. Res. 1205, $91^{\text {st }}$ Cong., 2d Sess. (1970). Most recently, Representative Jesse Jackson, Jr. proposed a constitutional amendment "respecting the right to a clean, safe, and sustainable environment." H.R.J. Res. 33, 108th Cong. (2003). Each of these proposals sought not only to elevate environmental protection to a Constitutional right, but also to give the federal government a clear mandate to regulate environmental matters. Without such a mandate, the government has had to rely on the commerce clause or other enumerated powers in order to assert jurisdiction over natural resources. Thus, the federal government may protect migratory birds that cross state lines, but lacks jurisdiction to protect all the habitats of such birds, because these habitats include state and private lands and non-navigable waters. State opposition to granting this power to the federal government may explain the failure of the proposed amendments.

10 SuOMEn PERUSTUSLAKi [Constitution] art. 20 (Fin.), translated in CONSTITUTIONS OF THE COUNTRIES OF THE WORLD, supra note [32]. Article 20 stems from a constitutional reform taking place in the mid 1990s in Finland aiming at providing a more "coherent set of fundamental rights" in Finland. See Stephen Davies, In Name or Nature? Implementing International Environmental Procedural Rights in the Post-Aarhus Environment: A Finnish Example, 9 ENV. L. REV. 190 (2007).

11 GRUNNLOV [Constitution] art. 110B (Nor.), translated in CONSTITUTIONS OF THE COUNTRIES OF THE WORLD, supra note [32].

12 These include among others: Albania, Belarus, Croatia, Czech Republic, Estonia, Hungary, Macedonia, Russia, Slovenia and Ukraine; See May, supra note 218, at 129-31. For example, the Hungarian Constitution states, "Hungary recognizes and implements everyone's right to a healthy environment." A MAGYAR KÜZTÁRSASÁG AlKotmÁNYA [Constitution] art. 18 (Hung.), translated in CONSTITUTIONS OF THE COUNTRIES OF THE WORLD, supra note [32]; see also Gyula Badni, The Right to Environment in Theory and Practice: The Hungarian Experience, 8 CONN. J. INT'L L. 439 (1993). 
States in the U.S. have the power to provide their citizens with rights additional to those contained in the federal constitution, and state constitutions revised or amended from 1970 to the present have added environmental protection among their provisions. See Ala. Const. art. VIII; Cal. Const. art. X, § 2; Fla. Const. art. II, § 7; Haw. Const. art. XI; Ill. Const. art. XI; La. Const. art. IX; Mass. Const. § 179; Mich. Const. art. IV, § 52; Mont. Const. art. IX, § 1; N.M. Const. art. XX, § 21; N.Y. Const. art. XIV; N.C. Const. art. XIV, § 5; Ohio Const. art. II, § 36; Pa. Const. art. I, § 27; R.I. Const. art. 1, § 17; Tex. Const. art. XVI, § 59; Utah Const. art. XVIII; Va. Const. art. XI, § 1. For discussions of these provisions, see: A. E. Dick Howard, State Constitutions and the Environment, 58 VA. L. REV. 193, 229 (1972); Roland M. Frye, Jr., Environmental Provisions in State Constitutions, 5 ENVTL. L. ReP. 50028-29 (1975); Stewart G. Pollock, State Constitutions, Land Use, and Public Resources: The Gift Outright, 1984 ANN. SuRV. AM. L. 13, 28-29; Robert A. McLaren, Comment, Environmental Protection Based on State Constitutional Law: A Call for Reinterpretation, 12 U. Haw. L. REV. 123, 126-27 (1990).; Carole L. Gallagher, The Movement to Create an Environmental Bill of Rights: From Earth Day 1970 to the Present, 9 ForDHAM ENVTL. L.J. 107 (1997). For a listing of all environmental provisions in state constitutions, see Bret Adams et al., Environmental and Natural Resources Provisions in State Constitutions, 22 J. LAND RESOURCES \& ENVTL. L. 73 (2002). The authors take a broad reading of the topic, including all provisions that touch on natural resources. They come to a total of 207 state constitutional provisions in 46 state constitutions.

The first constitutional recognition of environmental rights appeared in Pennsylvania. Two years after the initial federal constitution effort failed, April 14, 1970 was designated the first Earth Day. See Matthew Thor Kirsch, Upholding the Public Trust in State Constitutions, 46 DuKE L.J. 11691210 (1997). To mark the occasion, the Pennsylvania legislature approved a proposed amendment to the state constitution. The author of the proposal said he intended to "give our natural environment the same kind of constitutional protection that [is] given our political rights." Franklin L. Kury, The Pennsylvania Environmental Protection Amendment, PA. B. ASs'N Q., Apr. 1987, at 85, 87, quoted in Kirsch, supra $\mathrm{n} .30$ at 1170 . The proposed amendment was approved overwhelmingly by voters in the state, on May, 18, 1971. The vote was more than $3-1$ in favor of the amendment, with close to 2 million voters. See Franklin L. Kury, The Environmental Amendment to the Pennsylvania Constitution: Twenty Years Later and Largely Untested, 1 VILL. ENVTL. L.J. 123, 123-24 (1990). The provision, now Article I, section 27 of the state constitution, sets forth:

\section{Section 27. Natural resources and the public estate}

The people have a right to clean air, pure water, and to the preservation of the natural, scenic, historic and aesthetic values of the environment. Pennsylvania's public natural resources are the common property of all the people, including generations yet to come. As trustee of these resources, the Commonwealth shall conserve and maintain them for the benefit of all the people.

There are several evident features about this text. First, it declares the "people's" right to environmental amenities with a directive to the state to act as a trustee for the "public natural resources" of the state (excluding private property). The resources mentioned are declared to be common property and held for future as well as present generations.

Following this example, more than thirty of the fifty states in the United States $(60 \%)$ have added constitutional provisions that refer to environmental or natural resource protection as a state constitutional right or governmental duty. The intent of the provisions must be considered in the context of the federal system: unlike the federal government, which must act within the scope of conferred powers, state authorities may act unless prohibited from doing so. Thus, they may regulate the activities harming the environment without mention of the topic in the state constitution. Including provisions in the constitution must serve some other purpose than simply conferring legislative authority over environmental matters. The most compelling explanation is that the amendments were intended to elevate environmental protection as a fundamental value to a constitutional status above the states' legislative and regulatory norms. Another purpose appears in 
some state debates and constitutional texts: to expand standing to sue to allow public interest litigation on behalf of the environment.

A half dozen other states, like Hawaii, Illinois, Montana, and Texas followed Pennsylvania in adding a constitutional right to environment. Hawaii's Constitution, Article XI, section 9, reads:

Each person has the right to a clean and healthful environment, as defined by law relating to environmental quality, including control of pollution and resources. Any person may enforce this right against any party, public or private, through appropriate legal proceedings.

Illinois, Massachusetts and Montana all amended their constitutions in 1972 to similarly provide for a right to a clean and healthful environment. Massachusetts expressly guarantees the right to clean air and water, freedom from excessive and unnecessary noise, and the natural scenic, historic, and aesthetic qualities of their environment. Mass. Const. art. XLIX. Montana's amendment provides: The people shall have the right to clean air and water, freedom from excessive and unnecessary noise, and the natural, scenic, historic, and esthetic qualities of their environment; and the protection of the people in their right to the conservation development and utilization of the agricultural, mineral, forest, water, air and other natural resources is hereby declared to be a public purpose. Mont. Const. XLIX. This provision has been enforced by the courts, as the following case illustrates.

\section{Montana Environmental Information Center et al v. Department of Environmental Quality} 296 Mont. 207, 988 P.2d 1236 (1999)

Justice TERRY N. TRIEWEILER delivered the Opinion of the Court.

I 1 The Plaintiffs, Montana Environmental Information Center (MEIC), Clark Fork-Pend Oreille Coalition, and Women's Voices for the Earth, filed an amended complaint in the District Court for the First Judicial District in Lewis and Clark County in which the Department of Environmental Quality (DEQ) for the State of Montana was named as the Defendant and in which Seven-Up Pete Joint Venture (SPJV) subsequently intervened. Plaintiffs alleged, among other claims, that to the extent $\S 75-5-317(2)(\mathrm{j})$, MCA (1995) allows discharges of water from watering well or monitoring well tests, which degrade high quality waters without review pursuant to Montana's nondegradation policy found at $\S 75-5-303(3)$, MCA (1995), that statute is void for a violation of Article IX, Section 1(1) and (3) of the Montana Constitution. Plaintiffs sought an injunction suspending the exploration license that had been issued by DEQ to SPJV for pump tests to be performed at the site of its proposed gold mine. Both parties moved for summary judgment and following the submission of affidavits and oral testimony, the District Court held that absent a finding of actual injury, § 75-5-317(2)(j), MCA (1995) was not unconstitutional as applied and entered judgment for the DEQ. The Plaintiffs appeal from the judgment of the District Court. We reverse and remand for further review consistent with this opinion.

I 2 The issue on appeal is whether the Plaintiffs have demonstrated standing to challenge the constitutionality of $\S 75-5-317(2)(j)$, MCA (1995), and, if so, whether the statute implicates either Article II, Section 3 or Article IX, Section 1 of the Montana Constitution.

\section{Standing}

If 41 In Gryczan v. State (1997), 283 Mont. 433, 442-43, 942 P.2d 112, 118, we held that the following criteria must be satisfied to establish standing:(1) the complaining party must clearly allege past, present, or threatened injury to a property or civil right; and (2) the alleged injury must be distinguishable from the injury to the public generally, but the injury need not be exclusive to the complaining party.

I 42 In Missoula City-County Air Pollution Control Board v. Board of Environmental Review 
(1997), 282 Mont. 255, 937 P.2d 463, this Court considered the first prong of the two-part test and concluded that a threatened injury to the Local Board had been established by demonstrating "potential economic injury." Missoula City-County Air Pollution Control Bd., 282 Mont. at 262-63, 937 P.2d at 468. The court accepted the Local Board's argument that "it face[d] potential economic harm from the additional expenses necessary to monitor, collect and analyze data, and to develop a regulatory response which will ensure that Missoula air quality meets minimum federal standards in the face of increased air pollution from Stone Container." Missoula City-County Air Pollution Control Bd., 282 Mont. at 262, 937 P.2d at 468.

I 43 The second prong of the test for standing requires that the litigant distinguish his or her injury from injury to the general public. Gryczan, 283 Mont. at 442, 942 P.2d at 118 . However, the injury need not be exclusive to the litigant. Gryczan, 283 Mont. at 443, 942 P.2d at 118. In Gryczan we held that the plaintiffs had satisfied the second prong because they "presented evidence of specific psychological effects caused by the statute." We further found it significant that "to deny Respondents standing would effectively immunize the statute from constitutional review." Gryczan, 283 Mont. at 446, 942 P.2d at 120.

If 44 In Missoula City-County Air Pollution Control Board we held that the Local Board's "interest in the effective discharge of the obligations imposed upon it by law is the equivalent of the personal stake which would support standing of a private citizen of the Missoula airshed." Missoula City-County Air Pollution Control Bd., 282 Mont. at 262, 937 P.2d at 467. We further stated that:

It is clear to this Court that a citizen of Missoula, as one who breathes the air into which Stone Container is expelling pollutants, would have standing to bring this action.... In the same way as a citizen of the Missoula airshed is more particularly affected by the State Board's acts than is a citizen of another area, the interest of the Local Board is distinguishable from and greater than the interest of the public generally.

Missoula City-County Air Pollution Control Bd., 282 Mont. at 262, 937 P.2d at 467-68.

If 45 Based on these criteria, we conclude that the allegations in the Plaintiffs' complaint which are uncontroverted, established their standing to challenge conduct which has an arguably adverse impact on the area in the headwaters of the Blackfoot River in which they fish and otherwise recreate, and which is a source for the water which many of them consume. Whether Plaintiffs have demonstrated sufficient harm from the statute and activity complained of to implicate their constitutional rights and require strict scrutiny of the statute they have challenged, is a separate issue.

\section{Constitutional and Statutory Framework}

If 46 Appellants contend that $\S 75-5-317(2)(j)$, MCA (1995), violates their rights guaranteed by Article II, Section 3 and Article IX, Section 1 of the Montana Constitution.

If 47 Article II, Section 3 provides in relevant part that:

All persons are born free and have certain inalienable rights. They include the right to a clean and healthful environment....

Mont. Const. art. II, $\S 3$.

I 48 Article IX, Section 1 provides in relevant part as follows:

(1) The State and each person shall maintain and improve a clean and healthful environment in Montana for present and future generations.

(3) The legislature shall provide adequate remedies for the protection of the environmental life support system from degradation and provide adequate remedies to prevent unreasonable depletion and degradation of natural resources.

Mont. Const. art. IX, $§ 1$ (emphasis added).

I 49 Although enacted prior to the constitutional provisions relied on, the Plaintiffs contend that the nondegradation policy for high quality waters established by $\S 75-5-303$, MCA, of Montana's 
Water Quality Act is reasonably well designed to meet the constitution's objectives and that it is the minimum requirement which must be satisfied for a discharge which degrades the existing quality of Montana water. ...

If 50 Plaintiffs contend that the Constitution's environmental protections were violated y the legislature in 1995, when it amended $\S 75-5-317(2)(\mathrm{j})$, MCA to provide a blanket exception to the requirements of nondegradation review for discharges from water well or monitoring well tests without regard to the harm caused by those tests or the degrading effect that the discharges have on the surrounding or recipient environment. Section 75-5-317(2)(j), MCA (1995), provides in relevant part as follows:

(1) The categories or classes of activities identified in subsection (2) cause changes in water quality that are nonsignificant because of their low potential for harm to human health or the environment and their conformance with the guidance found in 75-5-301(5)(c).

(2) The following categories or classes of activities are not subject to the provisions of 75-5-303:

(j) discharges of water from water well or monitoring well tests . . . conducted in accordance with department approved water quality protection practices. ...

I 51 Plaintiffs contend that the groundwater discharged into the alluvia of the Landers Fork and Blackfoot Rivers and ultimately to the alluvial aquifers and the surface water of at least the Landers Fork River, degraded high quality waters by definition as established by the Department or its predecessor through A.R.M. 17.30.715(1)(b), which provides as follows:

(1) The following criteria will be used to determine whether certain activities or classes of activities will result in nonsignificant changes in existing water quality due to their low potential to affect human health or the environment. These criteria consider the quantity and strength of the pollutant, the length of time the changes will occur, and the character of the pollutant. Except as provided in (2) of this rule, changes in existing surface or groundwater quality resulting from the activities that meet all the criteria listed below are nonsignificant, and are not required to undergo review under 75-5-303, MCA:

(b) discharges containing carcinogenic parameters ... at concentrations less than or equal to the concentrations of those parameters in the receiving water. ...

I 52 Because discharges containing carcinogenic parameters, (i.e., discharged water containing concentrations of arsenic equal to $.009 \mathrm{mg} / \mathrm{l}$ ) greater than those in the receiving water (i.e., $.003 \mathrm{mg} / \mathrm{l}$ ) were allowed in this case, Plaintiffs contend that the discharges should not have been exempt from nondegradation review by DEQ's own standards and that they have, therefore, demonstrated the necessary harm for strict scrutiny of the blanket exemption provided for in $\S 75-5$ 317(2)(j), MCA.

\section{Constitutional Analysis}

I 54 In order to address the issue raised on appeal, it is necessary that we determine the threshold showing which implicates the rights provided for by Article II, Section 3 and Article IX, Section 1 of the Montana Constitution and the level of scrutiny to be applied to each provision. DEQ and SPJV contend, and the District Court agreed that actual danger to human health or the health of the environment must first be demonstrated. The Plaintiffs contend that Montana's constitutional provisions are intended to prevent harm to the environment; that degradation to the environment is all that need be shown; and that degradation was established in this case based on the DEQ's own adopted standard.

If 55 We have not had prior occasion to discuss the level of scrutiny which applies when the right to a clean and healthful environment guaranteed by Article II, Section 3 or those rights referred to in Article IX, Section 1 are implicated. Nor have we previously discussed the showing which must 
necessarily be made to establish that rights guaranteed by those two constitutional provisions are implicated. However, our prior cases which discuss other provisions of the Montana Constitution and the debate of those delegates who attended the 1972 Constitutional Convention, guide us in both respects.

In Butte Community Union v. Lewis (1986), 219 Mont. 426, 712 P.2d 1309, we held that:

If a fundamental right is infringed or a suspect classification established, the government has to show a "compelling state interest" for its action.

... in order to be fundamental, a right must be found within Montana's Declaration of Rights or be a right"without which other constitutionally guaranteed rights would have little meaning." In the Matter of C.H. (Mont.1984), [210 Mont. 184, 201], 683 P.2d 931, 940, 41 St.Rep. 997, 1007.

Butte Community Union, 219 Mont. at 430, 712 P.2d at 1311.

If 57 We held, however, that a middle-tier level of scrutiny will be applied when a right is implicated which, though not contained in our declaration of rights, is referred to in our constitution even though the constitutional provision in question is merely directive to the legislature. We held that:

A benefit lodged in our State Constitution is an interest whose abridgement requires something more than a rational relationship to a governmental objective.

. . . Where constitutionally significant interests are implicated by governmental classification, arbitrary lines should be condemned. Further, there should be balancing of the rights infringed and the governmental interest to be served by such infringement.

Butte Community Union, 219 Mont. at 434, 712 P.2d at 1313-14.

If $59 \mathrm{We}$ elaborated on the level of scrutiny for statutes or rules which implicate rights guaranteed in our declaration of rights in Wadsworth v. State (1996), 275 Mont. 287, 911 P.2d 1165. There we held that, "the inalienable right to pursue life's basic necessities is stated in the Declaration of Rights and is therefore a fundamental right." Wadsworth, 275 Mont. at 299, 911 P.2d at 1172.

I $60 \mathrm{We}$ also held in Wadsworth that the nature of interest affected by state action dictates the standard of review that we apply and that: "[t]he most stringent standard, strict scrutiny, is imposed when the action complained of interferes with the exercise of a fundamental right or discriminates against a suspect class." Wadsworth, 275 Mont. at 302, 911 P.2d at 1174(citations omitted).

9 61 In Wadsworth, we gave the following explanation of what is required by strict scrutiny:

Strict scrutiny of a legislative act requires the government to show a compelling state interest for its action. Shapiro [v. Thompson (1969)], 394 U.S. [618] at 634, 89 S.Ct. [1322] 1331 [22 L.Ed.2d 600]. When the government intrudes upon a fundamental right, any compelling state interest for doing so must be closely tailored to effectuate only that compelling state interest. [State v.] Pastos, [(1994), 269 Mont. 43, 47] 887 P.2d [199] at 202 (citing Zablocki v. Redhail (1978), 434 U.S. 374, 98 S.Ct. 673, 54 L.Ed.2d 618). In addition to the necessity that the State show a compelling state interest for invasion of a fundamental right, the State, to sustain the validity of such invasion, must also show that the choice of legislative action is the least onerous path that can be taken to achieve the state objective. Pfost v. State (1985), 219 Mont. 206, 216, 713 P.2d 495, 505.

Wadsworth, 275 Mont. at 302, 911 P.2d at 1174.

If 62 Finally, in language relevant to this case, we held in Wadsworth that, "while DOR's conflict of interest policy or rule is at issue rather than a statute, we, nevertheless, apply strict scrutiny analysis since the operation of that rule implicates Wadsworth's fundamental right to the opportunity to pursue employment." Wadsworth, 275 Mont. at 303, 911 P.2d at 1174 (emphasis added). 
If 63 Applying the preceding rules to the facts in this case, we conclude that the right to a clean and healthful environment is a fundamental right because it is guaranteed by the Declaration of Rights found at Article II, Section 3 of Montana's Constitution, and that any statute or rule which implicates that right must be strictly scrutinized and can only survive scrutiny if the State establishes a compelling state interest and that its action is closely tailored to effectuate that interest and is the least onerous path that can be taken to achieve the State's objective.

If 64 State action which implicates those rights provided for in Article IX, Section 1 would normally not be subject to strict scrutiny because those rights are not found in Montana's Declaration of Rights. Those rights would normally be subject to a middle-tier of scrutiny because lodged elsewhere in our state constitution. However, we conclude that the right to a clean and healthful environment guaranteed by Article II, Section 3, and those rights provided for in Article IX, Section 1 were intended by the constitution's framers to be interrelated and interdependent and that state or private action which implicates either, must be scrutinized consistently. Therefore, we will apply strict scrutiny to state or private action which implicates either constitutional provision.

If 65 A thorough review of the discussion and debate among the delegates to our 1972 Constitutional Convention leads us to the further conclusion that the nature of the environmental rights provided by Articles II and IX cannot be interpreted separately, but that it was the delegates' intention that the two provisions compliment each other and be applied in tandem. Therefore, we look to the records of the convention discussion and debate to determine the showing that must be made before the rights are implicated and strict scrutiny applied.

If 66 Article IX, Section 1 was reported to the floor of the constitutional convention by the Natural Resources and Agricultural Committee on March 1, 1972. Montana Constitutional Convention, Vol. IV at 1198-99. As originally proposed, however, Article IX, Section 1(1) required that "the state and each person . . . maintain and enhance the Montana environment for present and future generations." Montana Constitutional Convention, Vol. IV at 1200, March 1, 1972. It did not provide, as does the current provision, the obligation to "maintain and improve a clean and healthful environment." See Montana Constitutional Convention, Vol. IV at 1200, March 1, 1972; Mont. Const. art. IX, § 1(1). The provision, as introduced, was thought by members of the committee to be the strongest environmental protection provision found in any state constitution. Montana Constitutional Convention, Vol. IV at 1200, March 1, 1972. Delegate McNeil explained that descriptive adjectives were not included preceding the word environment such as healthful or unsoiled, because the majority felt that the current Montana environment encompassed all of those descriptive adjectives. Montana Constitutional Convention, Vol. IV at 1200, March 1, 1972. He further explained that descriptive adjectives were not originally included because:

The majority felt that the use of the word "healthful" would permit those who would pollute our environment to parade in some doctors who could say that if a person can walk around with four pounds of arsenic in his lungs or SO2 gas in his lungs and wasn't dead, that that would be a healthful environment. We strongly believe the majority does that our provision or proposal is stronger than using the word "healthful."

Montana Constitutional Convention, Vol. IV at 1201, March 1, 1972.

ๆ 67 In discussing the interrelationship of subsections (1) and (3), Delegate McNeil stated:

Subsection (3) mandates the Legislature to provide adequate remedies to protect the environmental life-support system from degradation. The committee intentionally avoided definitions, to preclude being restrictive. And the term "environmental life support system" is all-encompassing, including but not limited to air, water, and land; and whatever interpretation is afforded this phrase by the Legislature and courts, there is no question that it cannot be degraded.

Montana Constitutional Convention, Vol. IV at 1201, March 1, 1972 (emphasis added).

If 68 There were delegates including Delegate Campbell who felt that without descriptive adjectives, such as "clean and healthful" prior to the term "environment," Article IX, Section 1 lacked the force that the majority had intended. Montana Constitutional Convention, Vol. IV at 1204, March 
1, 1972. However, the proponents of Section 1 as introduced, insisted that the subsection require that the environment not only be maintained but improved. See Delegate John Anderson cmts. (Montana Constitutional Convention, Vol. IV at 1204, March 1, 1972).

I 69 Delegate McNeil explained the committee's concern about including "clean and healthful" as follows:

[T] he majority felt this would permit degradation of the present Montana environment to a level as defined in Illinois, which may be clean and healthful. And our intention was to permit no degradation from the present environment and affirmatively require enhancement of what we have now.

Montana Constitutional Convention, Vol. IV at 1205, March 1, 1972 (emphasis added).

I 70 In further discussing the interrelationship between subsections (1) and (3) of Article IX, Delegate McNeil stated:

The majority proposal before you now does recommend, as did Mr. Lindbergh, government monitoring. It goes further than that and directs the Legislature to provide remedies to prevent degradation. This is anticipatory.

Montana Constitutional Convention, Vol. IV at 126, March 1, 1972 (emphasis added).

The proposal mandates the legislature to prevent degradation and to prevent unreasonable depletion. Now, that includes private property.

Montana Constitutional Convention, Vol. V at 1221, March 1, 1972 (emphasis added).

$$
\cdots
$$

I 73 In concluding remarks in opposition to amending the committee majority's proposed Article IX, Section 1, Delegate McNeil gave the following explanation for the language being recommended:

We did not want the Supreme Court of this state or the Legislature to be able to say that the environment in Montana, as we know right now, can be degraded to a healthful environment. So our purpose in leaving that word out was to strengthen it. I would like also to remind the delegates that the Illinois provision does not contain subparagraph 3 of the majority proposal, [Article IX, Section 1(3) ] which speaks precisely to the point that concerned Jerry Cate so much, and that is there is no provision by which the Legislature can prevent and this is anticipatory can prevent unreasonable depletion of the natural resources. I submit if you will read that majority proposal again and again, you will find that it is the strongest of any constitution....

Montana Constitutional Convention, Vol. V at 1243, March 1, 1972.

I 74 Delegate Foster also gave the following defense of the language as originally proposed:

I feel that if we, as a Constitutional Convention of Montana, use our line of defense on the environment on the basis of healthful, then we, in fact, might as well forget it, because what I'm concerned about in Montana is not a healthful environment. This country is going to have to address itself to the question of a healthful environment. What I'm concerned about is an environment that is better than healthful. If all we have is a survivable environment, then we've lost the battle. We have nothing left of importance. The federal government will see to it one way or another, if it's in its power, that we have an environment in which we can manage to crawl around or to survive or to in some way stay "alive". But the environment that I'm concerned about is that stage of quality of the environment which is above healthful; and if we put in the Constitution that the only line of defense is a healthful environment and that I have to show, in fact, that my health is being damaged in order to find some relief, then we've lost the battle; so I oppose this amendment.

Montana Constitutional Convention, Vol. V at 1243-44, March 1, 1972. 
If 75 In the end advocates for adding the descriptive language "clean and healthful" prevailed. However, it was not on the basis that they wanted less protection than articulated by Delegates McNeil and Foster, it was because they felt the additional language was necessary in order to assure the objectives articulated by Delegates McNeil and Foster. See Delegate Campbell cmts. (Montana Constitutional Convention, Vol. V at 1246, March 1, 1972). It was agreed by both sides of the debate that it was the convention's intention to adopt whatever the convention could agree was the stronger language. See Delegate McNeil cmts. (Montana Constitutional Convention, Vol. IV at 1209, March 1, 1972).

I 76 Although Article IX, Section 1(1), (2), and (3) were all approved by the convention on March 1, 1972 (Montana Constitutional Convention, Vol. V at 1251, 1254-55, March 1, 1972) the right to a clean and healthful environment was not included in the Bill of Rights until six days later on March 7, 1972. On that date, Delegate Burkhart moved to add "the right to a clean and healthful environment" to the other inalienable rights listed in Article II, Section 3 of the proposed constitution. Montana Constitutional Convention, Vol. V at 1637, March 7, 1972. He explained his intention that it interrelate with those rights provided for and previously adopted in Article IX, Section 1. Montana Constitutional Convention, Vol. V at 1637, March 7, 1972. He also stated that it was his intention through the addition of this right to the Bill of Rights to give force to the language of the preamble to the constitution. Montana Constitutional Convention, Vol. V at 1637, March 7, 1972. Burkhart stated: "I think it's a beautiful statement, and it seems to me that what I am proposing here is in concert with what's proposed in that Preamble...." Montana Constitutional Convention, Vol. V at 1638, March 7, 1972. Delegate Eck concurred that including the additional language in Article II, Section 3, was consistent with the intention of the Natural Resources Committee when it reported Article IX, Section 1. Montana Constitutional Convention, Vol. V at 1638, March 7, 1972. The right to a clean and healthy environment was, therefore, included as a fundamental right by a vote of 79 to 7 . Montana Constitutional Convention, Vol. V at 1640, March 7, 1972. We have previously cited with approval the following language from 16 C.J.S. Constitutional Laws $§ 16$ (1984):

The prime effort or fundamental purpose, in construing a constitutional provision, is to ascertain and to give effect to the intent of the framers and of the people who adopted it. The court, therefore, should constantly keep in mind the object sought to be accomplished ... and proper regard should be given to the evils, if any, sought to be prevented or remedied....

General Agric. Corp. v. Moore (1975), 166 Mont. 510, 518, 534 P.2d 859, 864.

I 77 We conclude, based on the eloquent record of the Montana Constitutional Convention that to give effect to the rights guaranteed by Article II, Section 3 and Article IX, Section 1 of the Montana Constitution they must be read together and consideration given to all of the provisions of Article IX, Section 1 as well as the preamble to the Montana Constitution. In doing so, we conclude that the delegates' intention was to provide language and protections which are both anticipatory and preventative. The delegates did not intend to merely prohibit that degree of environmental degradation which can be conclusively linked to ill health or physical endangerment. Our constitution does not require that dead fish float on the surface of our state's rivers and streams before its farsighted environmental protections can be invoked. The delegates repeatedly emphasized that the rights provided for in subparagraph (1) of Article IX, Section 1 was linked to the legislature's obligation in subparagraph (3) to provide adequate remedies for degradation of the environmental life support system and to prevent unreasonable degradation of natural resources.

If 78 We conclude, therefore, that the District Court erred when it held that Montana's constitutional right to a clean and healthy environment was not implicated, absent a demonstration that public health is threatened or that current water quality standards are affected o such an extent that a significant impact has been had on either the Landers Fork or Blackfoot River.

If $79 \mathrm{We}$ conclude that the constitutional right to a clean and healthy environment and to be free from unreasonable degradation of that environment is implicated based on the Plaintiffs' demonstration that the pumping tests proposed by SPJV would have added a known carcinogen such as arsenic to the environment in concentrations greater than the concentrations present in the receiving water and that the DEQ or its predecessor after studying the issue and conducting hearings has concluded that discharges containing carcinogenic parameters greater than the concentrations of those 
parameters in the receiving water has a significant impact which requires review pursuant to Montana's policy of nondegradation set forth at $\S 75-5-303$, MCA. The fact that DEQ has a rule consistent with $\S 75-5-317(2)(\mathrm{j}), \mathrm{MCA}$ (1995), is of no consequence. As we have previously held in Wadsworth, the constitution applies to agency rules as well as to statutes.

I $80 \mathrm{We}$ conclude that for purposes of the facts presented in this case, $\S 75-5-303, \mathrm{MCA}$ is a reasonable legislative implementation of the mandate provided for in Article IX, Section 1 and that to the extent $\S 75-5-317(2)(j)$, MCA (1995) arbitrarily excludes certain "activities" from nondegradation review without regard to the nature or volume of the substances being discharged, it violates those environmental rights guaranteed by Article II, Section 3 and Article IX, Section 1 of the Montana Constitution. Our holding is limited to $\S 75-5-317(2)(\mathrm{j})$, MCA (1995), as applied to the facts in this case. We have not been asked to and do not hold that this section facially implicates constitutional rights.

If 81 Based on these holdings, we reverse the judgment of the District Court and remand to the District Court for strict scrutiny of the statutory provision in question, and in particular for a determination of whether there is a compelling state interest for the enactment of that statute based on the criteria we articulated in Wadsworth v. State.

If 82 The judgment of the District Court is reversed and this case is remanded for further proceedings consistent with this opinion.

\section{Questions \& Discussion}

1. Do you agree with those at the Constitutional Convention who argued that including the word "healthful" weakened the Constitutional guarantee? Does it depend on whether the word refers to humans or to the environment being full of health? Does "healthy environment" mean healthy for humans or an environment that is intrinsically healthy? What difference does it make?

2. How would you evaluate the benefits and drawbacks of the Montana Constitutional provision compared to traditional nuisance law?

3. The Montana Supreme Court further applied its constitutional provision in the case Cape-France Enterprises v. The Estate of Peed, 305 Mont. 513, 29 P.3d 1011 (2001), in which it held that "the protections and mandates of this provision to private action - and thus to private parties - as well" as to state action. Thus, "it would be unlawful for Cape-France, a private business entity, to drill a well on its property in the face of substantial evidence that doing so may cause significant degradation of uncontaminated aquifers and pose serious public health risks." The court held that it would be a violation of the state's obligation under the constitution for it to grant specific performance of a contract for the sale of the land in question. See Naber, Murky Waters: Private Action and the Right to a Clean and Healthful Environment - An examination of Cape-France Enterprises v. Estate of Peed, 64 MonT. L. REV. 357 (2003); B. Thompson, Constitutionalizing the Environment: The History and Future of Montana's Environmental Provisions, 64 MoNT.L.REV. 157 (2003)

\section{Comment: Litigating State Constitutional Protections}

More than a dozen state constitutions in the United States have enacted provisions that guarantee environmental rights. Not all of them are enforced to the extent of Montana's provision, however. Two major procedural hurdles have been encountered: self-execution and standing.

\section{Self-execution}

Some courts have held that constitutional provisions on the right to environment are non-selfexecuting and require legislative action before they can be enforced. When a state constitutional environmental provision is ambiguous as to its self-executing status, judges tend to declare that the provisions amount to statements of policy or affirmations of existing legislative authority, rather than new, enforceable rights or obligations. When the constitutional provision refers generally to conservation of resources, courts may find the terms too vague to be enforced without the courts being forced to engage in law-making in violation of the separation of powers. In such instances, 
individuals will be barred from invoking constitutional provisions unless and until the legislature enacts measures to establish precise regulations and standards governing the topic.

Courts in Pennsylvania, Louisiana and Michigan have declared their provisions to be selfexecuting or have found their provisions executed by legislative action. See Save Ourselves, Inc. v Louisiana Environmental Control Commission, 452 So. 2d 1151 (La. 1984); Mich. Const. art. 4, § 52. In the Pennsylvania case Commonwealth v. National Gettysburg Battlefield Tower, Inc., 302 A.2d 886 (Pa. Commw. Ct.), aff'd 311 A.2d 588 (Pa. 1973), the government sued a private company to enjoin its construction of an observation tower overlooking Gettysburg National Military Park. The lower court held that the provision imposed a self-executing duty on the government to protect the environment against private conduct as well as state action, because "the despoliation of the environment is an act to be expected, in our private ownership society, from public persons." Id. at 892 The court found that the constitutional provision was no vaguer than the guarantees of due process and equal protection and thus could be enforced. On the merits the trial and appellate courts held that construction of the tower did not violate the constitutional guarantee. The Pennsylvania Supreme Court affirmed, but split four ways on the rationale. One justice declined to join any opinion, but simply concurred in the result that upheld the decision below. Two justices affirmed without discussing the issue of self-execution while two others concluded that the constitutional provision was not self-executing. The opinion for the court identified a need for property owners to be able to plan for the use of their property, reasoning that without a more specific standard, "a property owner would not know and would have no way, short of expensive litigation, of finding out what he could do with his property." 311 A.2d 566 at 593 The Court considered that if the vaguelyworded provision were "self-executing, action taken under it would pose serious problems of constitutionality, under both the equal protection clause and the due process clause." Id., at 595. Two judges dissented, finding the provision self-executing and the proposed tower in violation of it because the provision "installed the common law public trust doctrine as a constitutional right to environmental protection susceptible to enforcement in an action in equity." Id. at 596.

A subsequent Pennsylvania case Payne v. Kassab, 21 A.2d 86 (Pa. Commw. Ct. 1973), aff'd 361 A.2d 263 (Pa. 1976), affirmed the self-executing nature of the Pennsylvania Constitution's Section 27. Citizens invoked the provision to challenge a street-widening project that would have encroached on a commons area in the town of Wilkes-Barre. Like the earlier case, however, the court decided on the merits that the action did not violate the constitutional guaranteed. The Supreme Court affirmed, 361 A.2d 263 (Pa. 1976) and developed a three part test for determining violations that "is so weak that litigants using it to challenge environmentally damaging projects are almost always unsuccessful." John Dernbach, Taking the Pennsylvania Constitution Seriously When it Protects the Environment: Part I - An Interpretive Framework for Article I, Section 27, 103 DICK. L. REV. 693, 696 (1999).

\section{Standing}

The United States Supreme Court began addressing the standing of individuals to bring lawsuits to protect the environment about the time many of the state constitutional provisions were being enacted. See United States v. Students Challenging Regulatory Agency Procedures, 412 U.S. 669 (1973); Sierra Club v. Morton, 405 U.S. 727 (1972). The decisions expanded standing to allow plaintiffs to sue for aesthetic or environmental injuries. In 1992, Lujan v. Defenders of Wildlife, 504 U.S. 555 (1992) reiterated, however, that those seeking to sue must meet the difficult standing requirements of an imminent injury-in-fact, a causal connection between the injury and the conduct complained of, and an available remedy that will redress the injury. Id. at 560-61.

Many of the state constitutional provisions appear intended to liberalize standing rules. In Illinois, the constitutional right to a clean and healthful environment creates no new cause of action, City of Elgin v. County of Cook, 660 N.E.2d 875 (Ill. 1995).but it does give "standing to an individual to bring an environmental action for a grievance common to members of the public," even in cases where a resident may not be able to demonstrate the "particularized" harm that is normally required. Glisson v. City of Marion, 720 N.E.2d 1034, 1041 (Ill. 1999) In Glisson, however, the Illinois Court 
found that the constitutional guarantee was not broad enough to grant standing to an individual who sought to protect biodiversity through obtaining a review of the construction of a dam that would impact two endangered species.

Although not all courts have given effect to this intent, some of them have broadly interpreted the standards in favor of plaintiffs. Pennsylvania courts fall in the latter category. The state's requirements for standing demand that the plaintiffs have a substantial, direct, and immediate interest in the subject matter of the litigation. The Pennsylvania Supreme Court has indicated that environmental litigants may meet this test because "[a]esthetic and environmental well-being are important aspects of the quality of life in our society." Franklin Township v. Commonwealth, Department of Environmental Resources, 452 A.2d 718, 720 (Pa. 1982). Because section 27 establishes a local government's duty to protect its citizen's quality of life, localities may challenge the state's issuance of a permit for establishment of a toxic waste disposal site. Id. Other decisions have affirmed that Section 27 should "normally" be broadly construed, "especially where a potentially affected locality or private citizen, or specifically empowered watchdog agency, seeks review of an environmental sensitive ... decision." Commonwealth, Pa. Game Comm'n v. Commonwealth, Dept. of Envtl. Resources, 509 A.2d 877, 883-84 (Pa. Comm2. Ct. 1986), aff'd 555 A.2d 812 (Pa. 1989).

The Supreme Court of Hawai'i has also given broad standing to private individuals to enforce environmental laws, relying on its constitution, art. XI, sec. 9. In Life of the Land v. Land Use Comm'n of the State of Hawai'i, 623 P.2d 431 (Haw. 1981) the court granted standing to an environmental organization which sought to challenge a reclassification of certain lands which were not owned by any of the organization's members. The Supreme Court held that the plaintiffs had standing due to their "aesthetic and environmental interests," which the court deemed to "personal" and "special" interests or rights guaranteed by Art. XI, sec. 9 of the Constitution. Subsequent cases have affirmed that the Constitutional provision gives individuals standing to sue for environmental damage or to enforce environmental laws. See Richard v. Metcalf, 921 P.2d 122 (Haw. 1997); Kahuna Sunset Owners Ass'n v. Mahui County Council, 948 P.2d 122 (Haw. 1997).

Where the procedural hurdles have been overcome or are absent, as in about one-third of the states with constitutional references to the environment, state courts have enforced environmental rights. This is also the case in other countries which have enacted constitutional guarantees of environmental rights, including many developing countries where the concept of sustainable development has been critically important. South Africa is one of them.

\section{B. South Africa}

\section{Fuel Retailers Association of Southern Africa v Director-General Environmental Management, Department of Agriculture, Conservation and Environment, Mpumalanga Province, and Others Case no CCT 67/06; ILDC 783 (ZA 2007) (footnotes omitted or renumbered)}

\section{Ngcobo J:}

\section{Introduction}

[1] This application for leave to appeal against the decision of the Supreme Court of Appeal concerns the nature and scope of the obligations of environmental authorities when they make decisions that may have a substantial detrimental impact on the environment. In particular, it concerns the interaction between social and economic development and the protection of the environment. It arises out of a decision by the Department of Agriculture, Conservation and Environment, Mpumalanga province (the Department), the third respondent, to grant the Inama Family Trust (the Trust) authority in terms of section 22(1) of the Environment Conservation Act, 1989 (ECA) [Act 73 of 1989], to construct a filling station on a property in White River, Mpumalanga (the property). 


\section{Factual background}

[8] During July 2000, the Trust, through an environmental consultant firm, Globecon Environmental Management Services (Globecon), applied to the Department for authorisation to construct a filling station on the property in terms of these provisions. A scoping report, a geotechnical and geohydrological report (the Geo3 report) were submitted in support of the application. ${ }^{13}$ The scoping report dealt with, among other matters, socio-economic factors and the presence of an aquifer in the property. In addition, the scoping report contained an evaluation of the impact of the proposed filling station, identified certain areas of concern and proposed recommendations to address these concerns.

[9] Under the heading "Socio-Economic Components", the scoping report referred to the implications of the proposed filling station for noise, visual impacts, traffic, municipal services, safety and crime, and cultural and historical sites. It also dealt with the feasibility of the proposed filling station and stated that-

Various other locations do exist for the proposed development, as the positioning of a filling station is dictated by traffic flow, visibility, availability of land and the location of other filling stations in the area.

As the proposed filling station is directly targeting traffic moving between White River, Hazyview and the Numbi Gate of the Kruger National Park, a specific location along the said route was identified. Once the site was identified a feasibility study was done based on locating the filling station at the specific site. Once the feasibility of the filling station on the specific site was identified, and the availability of the property was confirmed, no other options were considered.

[10] One of the issues identified in the report as requiring attention was the protection of an existing aquifer, a significant clean groundwater resource below the surface of the property. In the past this aquifer had been used to augment the water supply in White River. The report noted that the aquifer needed protection from pollution. The report recommended that the water quality of the aquifer through the borehole should be tested bi-annually. It proposed that if the Department of Water Affairs and Forestry (Water Affairs and Forestry) required it, an impermeable layer should be installed in the base of the pit to ensure that no contaminants from the tanks reach the aquifer. In addition, it recommended that a reconciliation programme should be in place to detect any leakage. These recommendations were made in the light of the Geo3 report.

[11] The applicant, through its environmental consultants, Ecotechnik, objected to the construction of the proposed filling station on several grounds, one being that the quality of the water in the aquifer might be contaminated. Ecotechnik submitted an evaluation report which criticised the consideration of alternatives to the development as being vague and non-specific and pointed out that "demand and activity alternatives were not investigated." The report also took issue with the manner in which the public participation process had been conducted, pointing out that there were interested persons who had not had the opportunity to express their views on a proposed filling station that might affect them.

\footnotetext{
${ }^{13}$ A scoping report is an environmental impact report that must be submitted in support of an application for authorisation under section 22(1) of ECA. Section 26, which empowers the Minister to make regulations concerning the scope and content of the environmental reports envisaged in section 22(1), contemplates that reports will include matters such as the identification of the economic and social interests which may be affected by the proposed activity; the extent and the nature of the effect of the proposed activity on social and economic interests; and how the adverse impact is to be minimised. By regulations regarding activities identified under section 21(1), GN R1183 of 5 September 1997, the Minister published the regulations concerning the scope and the contents of reports. These reports have come to be known as "scoping reports". The provisions of ECA relating to the nature and scope of the environmental authority's obligation when considering an application for authorisation under section 22(1), as well as the scope and contents of the report that must be submitted in support of such application, must be understood in the light of the provisions of NEMA.
} 
[12] There was a further exchange of reports by the opposing consultants which dealt with the adequacy or otherwise of the proposed measures for the prevention of the contamination of the aquifer. In the light of these reports and in particular, the existence of the aquifer, the Department referred the Geo3 report together with the objections raised by the applicant to Water Affairs and Forestry for comment.

[13] In a very brief response, Water Affairs and Forestry accepted the Geo3 report and, on the issue of underground water, required "[t]he proposed developer [to] ensure that no pollution of the groundwater ... take[s] place. And [that it] must be monitored as set out in the report and in accordance [with] all the relevant Regulations as set out by the Dept of Water Affairs and Forestry." Nothing was said about the installation of an impermeable layer, which according to the scoping report was to be installed if Water Affairs and Forestry required this. However, it subsequently transpired that the Water Quality Management and Water Utilization divisions of Water Affairs and Forestry had neither received nor commented on the Geo3 report.

[14] The application was considered in the first instance by Mr Hlatshwayo, the Deputy-Director in the Department. On 9 January 2002 authorisation was granted over the objection of the applicant. A record of decision was issued, which contained the decision and conditions upon which authorisation was granted. This decision authorised the construction of a filling station, three fuel tanks, a convenience store, a canopy, ablution facilities and driveways providing access to and from the nearby streets. The record of decision was signed by Dr Batchelor, the Director of Environmental Management in the Department.

[16] The applicant lodged an appeal against this decision. One of the grounds of appeal was that the need, desirability and sustainability of the proposed filling station had not been considered. It was alleged that this aspect was not addressed in the scoping report submitted by Globecon. It was also pointed out that the proposed filling station was within a radius of five kilometres from six other filling stations that adequately served the needs of the community. The applicant alleged that there had recently been a decline in the growth of fuel consumption in White River. The viability of existing filling stations would be affected and this had been exacerbated by the introduction of three new filling stations in the area.

\section{Issues presented}

[34] ... The questions which fall to be considered in this application are therefore, firstly, the nature and scope of the obligation to consider the social, economic and environmental impact of a proposed development; second, whether the environmental authorities complied with that obligation; and, if the environmental authorities did not comply with that obligation, the appropriate relief.

[35] Before addressing these issues, it is necessary to consider two preliminary matters. The first is the proper cause of action in this application. The other is whether the application raises a constitutional matter, and if so, whether it is in the interests of justice to grant leave to appeal.

\section{The proper cause of action}

[39] . . In the course of oral argument it became clear that the main ground of attack was that the environmental authorities failed to consider the impact of the proposed filling station on socioeconomic conditions, a matter which they were required to consider. The central question in this application therefore is whether the environmental authorities failed to take into consideration matters that they were required to consider prior to granting the authorisation under section 22(1) of ECA.

\section{Does the application raise a constitutional issue?}

[40] Section 24 of the Constitution guarantees to everyone the right to a healthy environment and contemplates that legislation will be enacted for the protection of the environment. ECA and NEMA are legislation which give effect to this provision of the Constitution. The question to be considered in this application is the proper interpretation of the relevant provisions of ECA and NEMA and, in 
particular, the nature of the obligations imposed by these provisions on the environmental authorities. The proper interpretation of these provisions raises a constitutional issue. So, too, does the application of PAJA. It follows therefore that the present application raises a constitutional issue.

\section{Is it in the interests of justice to grant leave to appeal?}

[41] This case raises an important question concerning the obligation of state organs when making decisions that may have a substantial impact on the environment. In particular, it concerns the nature and scope of the obligation to consider socio-economic conditions. The need to protect the environment cannot be gainsaid. So, too, is the need for social and economic development. How these two compelling needs interact, their impact on decisions affecting the environment and the obligations of environmental authorities in this regard, are important constitutional questions. In these circumstances, it is therefore in the interests of justice that leave to appeal be granted to consider these issues.

[42] In order to put the issues involved in this case in context and to evaluate the cogency of the constitutional challenge, it is necessary to understand both the constitutional and the legislative frameworks for the protection and management of the environment.

\section{The relevant constitutional provision}

[43] The Constitution deals with the environment in section 24 and proclaims the right of everyone-

(a) to an environment that is not harmful to their health or well-being; and

(b) to have the environment protected, for the benefit of present and future generations, through reasonable legislative and other measures that-

(i) prevent pollution and ecological degradation;

(ii) promote conservation; and

(iii) secure ecologically sustainable development and use of natural resources while promoting justifiable economic and social development.

\section{Sustainable development}

[44] What is immediately apparent from section 24 is the explicit recognition of the obligation to promote justifiable "economic and social development". Economic and social development is essential to the well-being of human beings. ${ }^{14}$ This Court has recognised that socio-economic rights that are set out in the Constitution are indeed vital to the enjoyment of other human rights guaranteed in the Constitution. ${ }^{15}$ But development cannot subsist upon a deteriorating environmental base. Unlimited development is detrimental to the environment and the destruction of the environment is detrimental to development. Promotion of development requires the protection of the environment. Yet the environment cannot be protected if development does not pay attention to the costs of environmental destruction. The environment and development are thus inexorably linked. And as has been observed-

"[E]nvironmental stresses and patterns of economic development are linked one to another. Thus agricultural policies may lie at the root of land, water, and forest degradation. Energy policies are associated with the global greenhouse effect, with acidification, and with deforestation for fuelwood in many developing nations. These stresses all threaten economic development. Thus economics and ecology must be completely integrated in decision making

14 Declaration on the Right to Development adopted by General Assembly Resolution 41/128 of 4 December 1986, http://www.un.org/documents/ga/res/41/a41r128.htm, accessed on 4 June 2007. Article 1 asserts that "[t]he right to development is an inalienable human right". The Preamble describes development as "a comprehensive economic, social, cultural and political process, which aims at the constant improvement of the well-being of the entire population".

15 Government of the Republic of South Africa and Others v Grootboom and Others 2001 (1) SA 46 (CC); 2000 (11) BCLR 1169 (CC). 
and lawmaking processes not just to protect the environment, but also to protect and promote development. Economy is not just about the production of wealth, and ecology is not just about the protection of nature; they are both equally relevant for improving the lot of humankind." 16

[45] The Constitution recognises the interrelationship between the environment and development; indeed it recognises the need for the protection of the environment while at the same time it recognises the need for social and economic development. It contemplates the integration of environmental protection and socio-economic development. It envisages that environmental considerations will be balanced with socio-economic considerations through the ideal of sustainable development. This is apparent from section 24(b)(iii) which provides that the environment will be protected by securing "ecologically sustainable development and use of natural resources while promoting justifiable economic and social development". Sustainable development and sustainable use and exploitation of natural resources are at the core of the protection of the environment.

\section{The concept of sustainable development in international law}

[46] Sustainable development is an evolving concept of international law. Broadly speaking its evolution can be traced to the 1972 Stockholm Conference. That Conference stressed the relationship between development and the protection of the environment, in particular, the need "to ensure that development is compatible with the need to protect and improve [the] environment for the benefit of their population". ${ }^{17}$ The principles which were proclaimed at this conference provide a setting for the development of the concept of sustainable development. ${ }^{18}$ Since then the concept of sustainable development has received considerable endorsement by the international community. ${ }^{19}$ Indeed in 2002 people from over 180 countries gathered in our country for the Johannesburg World Summit on Sustainable Development (WSSD) to reaffirm that sustainable development is a world priority. ${ }^{20}$

[47] But it was the report of the World Commission on Environment and Development (the Brundtland Report) which "coined" the term "sustainable development". ${ }^{21}$ The Brundtland Report defined sustainable development as "development that meets the needs of the present without compromising the ability of future generations to meet their own needs". It described sustainable development as-

"[i]n essence ... a process of change in which the exploitation of resources, the direction of investments, the orientation of technological development; and institutional change are all in harmony and enhance both current and future potential to meet human needs and aspirations".

16 Report of the World Commission on Environment and Development: Our Common Future (Brundtland Report), http://www.un.org/esa/sustdev/documents/docs_key_conferences.htm, link: General Assembly 42nd Session: Report of the World Commission on Environment and Development, accessed on 4 June 2007. Chapter 1 at para 42 .

17 Principle 13 of the Declaration of the United Nations Conference on the Human Environment, held in Stockholm 1972, http://www.unep.org/Documents/Default.asp?DocumentID=97\&ArticleID=1503, accessed on 4 June 2007.

18 Separate Opinion of Vice-President Weeramantry in Gabčíkovo-Nagymaros Project (Hungary/Slovakia) 37 I.L.M. 162 (1998).

19 Id.

20 Segger and Weeramantry (eds) Sustainable Justice: Reconciling Economic, Social and Environmental Law (Martinus Nijhoff, Leiden 2005) 561.

21 Sands Principles of International Environmental Law 2 ed (Cambridge University Press, Cambridge 2003) 252. 
[48] This report argued for a merger of environmental and economic considerations in decisionmaking and urged the proposition that "the goals of economic and social development must be defined in terms of sustainability". It called for a new approach to development - "a type of development that integrates production with resource conservation and enhancement, and that links both to the provision for all of an adequate livelihood base and equitable access to resources." The concept of sustainable development, according to the report, "provides a framework for the integration of environment[al] policies and development strategies".

[49] The 1992 Rio Conference made the concept of sustainable development a central feature of its Declaration. ${ }^{22}$ The Rio Declaration is especially important because it reflects a real consensus in the international community on some core principles of environmental protection and sustainable development. ${ }^{23}$ It developed general principles on sustainable development and provided a framework for the development of the law of sustainable development.

[50] At the heart of the Rio Declaration are Principles 3 and 4. Principle 3 provides that "[t]he right to development must be fulfilled so as to equitably meet developmental and environmental needs of present and future generations." Principle 4 provides that "[i]n order to achieve sustainable development, environmental protection shall constitute an integral part of the development process and cannot be considered in isolation from it." The idea that development and environmental protection must be reconciled is central to the concept of sustainable development. At the core of this Principle is the principle of integration of environmental protection and socio-economic development.

[51] Commentators on international law have understandably refrained from attempting to define the concept of sustainable development. Instead they have identified the evolving elements of the concept of sustainable development. ${ }^{24}$ These include the integration of environmental protection and economic development (the principle of integration); sustainable utilisation of natural resources (the principle of sustainable use and exploitation of natural resources); the right to development; the pursuit of equity in the use and allocation of natural resources (the principle of intra-generational equity); the need to preserve natural resources for the benefit of present and future generations (the principle of inter-generational and intra-generational equity); and the need to interpret and apply rules of international law in an integrated systematic manner.

[52] The principle of integration of environmental protection and development reflects a-

“... commitment to integrate environmental considerations into economic and other development, and to take into account the needs of economic and other social development in crafting, applying and interpreting environmental obligations."

This is an important aspect of sustainable development because "its formal application requires the collection and dissemination of environmental information, and the conduct of environmental impact

22 The United Nations Conference on Environment and Development was held in Rio de Janeiro, Brazil on 314 June 1992, http://www.un.org/documents/ga/conf151/aconf15126-1annex1.htm, accessed on 4 June 2007. This Conference adopted among other instruments, the Rio Declaration on Environment and Development (the Rio Declaration).

23 Boyle and Freestone (eds) International Law and Sustainable Development: Past Achievements and Future Challenges (Oxford University Press, Oxford 1999) 4.

24

... Sands identifies five recurring elements which appear to comprise the legal concept of sustainable development as reflected in international agreements. These are:

- "the need to take into consideration the needs of present and future generations;

- the acceptance, on environmental protection grounds, of limits placed upon the use and exploitation of natural resources;

- the role of equitable principles in the allocation of rights and obligations;

- the need to integrate all aspects of environment and development; and

- the need to interpret and apply rules of international law in an integrated and systemic manner." 
assessments." The practical significance of the integration of the environmental and developmental considerations is that environmental considerations will now increasingly be a feature of economic and development policy.

[53] The principle of integration of environmental protection and socio-economic development is therefore fundamental to the concept of sustainable development. Indeed economic development, social development and the protection of the environment are now considered pillars of sustainable development. As recognised in the WSSD, States have assumed-

“... a collective responsibility to advance and strengthen the interdependent and mutually reinforcing pillars of sustainable development - economic development, social development and environmental protection - at the local, national, regional and global levels." ${ }^{25}$

[54] The concept of sustainable development has received approval in a judgment of the International Court of Justice. This much appears from the judgment of the International Court of Justice in Gabčikovo-Nagymaros Project (Hungary/Slovakia) where the Court held-

"Throughout the ages, mankind has, for economic and other reasons, constantly interfered with nature. In the past, this was often done without consideration of the effects upon the environment. Owing to new scientific insights and to a growing awareness of the risks for mankind-for present and future generations - of pursuit of such interventions at an unconsidered and unabated pace, new norms and standards have been developed, set forth in a great number of instruments during the last two decades. Such new norms have to be taken into consideration, and such new standards given proper weight, not only when States contemplate new activities but also when continuing with activities begun in the past. This need to reconcile economic development with protection of the environment is aptly expressed in the concept of sustainable development." 26

[55] The integration of economic development, social development and environmental protection implies the need to reconcile and accommodate these three pillars of sustainable development. Sustainable development provides a framework for reconciling socio-economic development and environmental protection. This role of the concept of sustainable development as a mediating principle in reconciling environmental and developmental considerations was recognised by VicePresident Weeramantry in a separate opinion in Gabčíkovo-Nagymaros, when he said-

"The Court must hold the balance even between the environmental considerations and the development considerations raised by the respective Parties. The principle that enables the Court to do so is the principle of sustainable development."27

[56] It is in the light of these developments in the international law of environment and sustainable development that the concept of sustainable development must be construed and understood in our law.

\section{The concept of sustainable development in our law}

[57] As in international law, the concept of sustainable development has a significant role to play in the resolution of environmentally related disputes in our law. It offers an important principle for the resolution of tensions between the need to protect the environment on the one hand, and the need for

25 United Nations Department of Economic and Social Affairs - Division for Sustainable Development Johannesburg Declaration on Sustainable Development 2002 para 5, http://www.un.org/esa/sustdev /documents/WSSD_POI_PD/English/POI_PD.htm, accessed on 4 June 2007.

26 Gabčíkovo-Nagymaros Project (Hungary/Slovakia) 37 I.L.M. 162 (1998) 200 at para 140. In a Separate Opinion, Vice-President Weeramantry held that the concept of sustainable development is part of international customary law. See Separate Opinion at 207.

27 Separate opinion at 204. 
socio-economic development on the other hand. In this sense, the concept of sustainable development provides a framework for reconciling socio-economic development and environmental protection.

[58] Sustainable development does not require the cessation of socio-economic development but seeks to regulate the manner in which it takes place. It recognises that socio-economic development invariably brings risk of environmental damage as it puts pressure on environmental resources. It envisages that decision-makers guided by the concept of sustainable development will ensure that socio-economic developments remain firmly attached to their ecological roots and that these roots are protected and nurtured so that they may support future socio-economic developments.

[59] NEMA, which was enacted to give effect to section 24 of the Constitution, embraces the concept of sustainable development. Sustainable development is defined to mean "the integration of social, economic and environmental factors into planning, implementation and decision-making for the benefit of present and future generations". This broad definition of sustainable development incorporates two of the internationally recognised elements of the concept of sustainable development, namely, the principle of integration of environmental protection and socio-economic development, and the principle of inter-generational and intra-generational equity. In addition, NEMA sets out some of the factors that are relevant to decisions on sustainable development. These factors largely reflect international experience. But as NEMA makes it clear, these factors are not exhaustive. $^{28}$

[60] One of the key principles of NEMA requires people and their needs to be placed at the forefront of environmental management - batho pele. It requires all developments to be socially, economically and environmentally sustainable. Significantly for the present case, it requires that the social, economic and environmental impact of a proposed development be "considered, assessed and evaluated" and that any decision made "must be appropriate in the light of such consideration and assessment". This is underscored by the requirement that decisions must take into account the interests, needs and values of all interested and affected persons.

[61] Construed in the light of section 24 of the Constitution, NEMA therefore requires the integration of environmental protection and economic and social development. It requires that the interests of the environment be balanced with socio-economic interests. Thus, whenever a development which may have a significant impact on the environment is planned, it envisages that there will always be a need to weigh considerations of development, as underpinned by the right to socio-economic development, against environmental considerations, as underpinned by the right to environmental protection. In this sense, it contemplates that environmental decisions will achieve a balance between environmental and socio-economic developmental considerations through the concept of sustainable development.

${ }^{28}$ Section 2(4)(a) of NEMA provides:

"Sustainable development requires the consideration of all relevant factors including the following:

(i) That the disturbance of ecosystems and loss of biological diversity are avoided, or, where they cannot be altogether avoided, are minimised and remedied;

(ii) that pollution and degradation of the environment are avoided, or, where they cannot be altogether avoided, are minimised and remedied;

(iii) that the disturbance of landscapes and sites that constitute the nation's cultural heritage is avoided, or where it cannot be altogether avoided, is minimised and remedied;

(iv) that waste is avoided, or where it cannot be altogether avoided, minimised and re-used or recycled where possible and otherwise disposed of in a responsible manner;

(v) that the use and exploitation of non-renewable natural resources is responsible and equitable, and takes into account the consequences of the depletion of the resource;

(vi) that the development, use and exploitation of renewable resources and the ecosystems of which they are part do not exceed the level beyond which their integrity is jeopardised;

(vii) that a risk-averse and cautious approach is applied, which takes into account the limits of current knowledge about the consequences of decisions and actions; and

(viii) that negative impacts on the environment and on people's environmental rights be anticipated and prevented, and where they cannot be altogether prevented, are minimised and remedied." 
[62] To sum up therefore NEMA makes it abundantly clear that the obligation of the environmental authorities includes the consideration of socio-economic factors as an integral part of its environmental responsibility. ${ }^{29}$ It follows therefore that the parties correctly accepted that the Department was obliged to consider the impact of the proposed filling station on socio-economic conditions. It is within this context that the nature and scope of the obligation to consider socioeconomic factors, in particular, whether it includes the obligation to assess the cumulative impact of the proposed filling station and existing ones, and the impact of the proposed filling station on existing ones....

\section{The relevant provisions of NEMA}

[63] The provisions of NEMA which are relevant to this case and which were relied upon by the applicant are those that contain the national environmental management principles, the general objectives of integrated environmental management and those that deal with the implementation of these principles and objectives....

[67] NEMA principles "apply ... to the actions of all organs of state that may significantly affect the environment". They provide not only the general framework within which environmental management and implementation decisions must be formulated, but they also provide guidelines that should guide state organs in the exercise of their functions that may affect the environment. Perhaps more importantly, these principles provide guidance for the interpretation and implementation not only of NEMA but any other legislation that is concerned with the protection and management of the environment. It is therefore plain that these principles must be observed as they are of considerable importance to the protection and management of the environment.

[68] Apart from these principles, NEMA contemplates the integration of environmental management activities and to this extent it outlines the general objectives of integrated environmental management. Section 23 of NEMA sets out these general objectives. These include the objectives to promote the integration of the national environmental management principles into decisions that may significantly affect the environment; and to identify, predict and evaluate actual and potential impact on the environment, socio-economic conditions and cultural heritage. Their apparent purpose is to minimise the negative impact on the environment and socio-economic conditions and to promote compliance with the principles of environmental management.

[69] The general objectives of integrated environmental management are furthered by section 24 which deals with the implementation procedures. These require, among other things, that the potential impact on the environment, socio-economic conditions and cultural heritage of activities that require authorisation under section 22(1) of ECA and which may significantly affect the environment "must be considered, investigated and assessed prior to their implementation and reported upon to the organ of state charged by law with authorising ... the implementation of an activity". To underscore the importance of this requirement, subsection 24(7) requires that any investigation "must, as a minimum" investigate the potential impact, including the cumulative effects of the proposed development on the environment, socio-economic conditions and cultural heritage. The provisions of section 24(7) must of course be read and understood in the light of the regulations that the Minister is empowered to make concerning the scope and the contents of reports that must be submitted for authorisation required by section 22(1) of ECA.

[70] Against this background, I now turn to consider the nature and the scope of the obligation to consider socio-economic conditions.

\section{The nature and the scope of the obligation to consider socio-economic conditions}

29 This principle was considered in the following cases: BP Southern Africa (Pty) Ltd v MEC for Agriculture, Conservation, Environment and Land Affairs 2004 (5) SA 124 (W) at 140E-151H; Turnstone Trading CC v Director General Environmental Management, Department of Agriculture, Conservation \& Development, case no 3104/04 (T), 11 March 2005, unreported, at paras 17-19; MEC for Agriculture, Conservation, Environment and Land Affairs v Sasol Oil (Pty) Ltd and Another 2006 (5) SA 483 (SCA) at para 15. 
[71] The nature and the scope of the obligation to consider the impact of the proposed development on socio-economic conditions must be determined in the light of the concept of sustainable development and the principle of integration of socio-economic development and the protection of the environment. Once it is accepted, as it must be, that socio-economic development and the protection of the environment are interlinked, it follows that socio-economic conditions have an impact on the environment. A proposed filling station may affect the sustainability of existing filling stations with consequences for the job security of the employees of those filling stations. But that is not all; if the proposed filling station leads to the closure of some or all of the existing filling stations, this has consequences for the environment. Filling stations have a limited end use. The underground fuel tanks and other infrastructure may have to be removed and land may have to be rehabilitated.

[72] Apart from this, the proliferation of filling stations in close proximity to one another may increase the pre-existing risk of adverse impact on the environment. The risk that comes to mind is the contamination of underground water, soil, visual intrusion and light. An additional filling station may significantly increase this risk and increase environmental stress. Mindful of this possibility, NEMA requires that the cumulative impact of a proposed development, together with the existing developments on the environment, socio-economic conditions and cultural heritage must be assessed. The cumulative effect of the proposed development must naturally be assessed in the light of existing developments. A consideration of socio-economic conditions therefore includes the consideration of the impact of the proposed development not only in combination with the existing developments, but also its impact on existing ones.

[73] This approach to the scope of the obligation to consider socio-economic conditions is consistent with the concept of sustainable development under our legislation.

…

[78] What must be stressed here is that the objective of considering the impact of a proposed development on existing ones is not to stamp out competition; it is to ensure the economic, social and environmental sustainability of all developments, both proposed and existing ones. Environmental concerns do not commence and end once the proposed development is approved. It is a continuing concern. The environmental legislation imposes a continuing, and thus necessarily evolving, obligation to ensure the sustainability of the development and to protect the environment. As the International Court of Justice observed-

"in the field of environmental protection, vigilance and prevention are required on account of the often irreversible character of damage to the environment and of the limitations inherent in the very mechanism of reparation of this type of damage."

[79] There are two points that must be stressed here. First, the Constitution, ECA and NEMA do not protect the existing developments at the expense of future developments. What section 24 requires, and what NEMA gives effect to, is that socio-economic development must be justifiable in the light of the need to protect the environment. The Constitution and environmental legislation introduce a new criterion for considering future developments. Pure economic factors are no longer decisive. The need for development must now be determined by its impact on the environment, sustainable development and social and economic interests. The duty of environmental authorities is to integrate these factors into decision-making and make decisions that are informed by these considerations. This process requires a decision-maker to consider the impact of the proposed development on the environment and socio-economic conditions.

[80] Second, the objective of this exercise, as NEMA makes it plain, is both to identify and predict the actual or potential impact on socio-economic conditions and consider ways of minimising negative impact while maximising benefit. Were it to be otherwise, the earth would become a graveyard for commercially failed developments. And this in itself poses a potential threat to the environment. One of the environmental risks associated with filling stations is the impact of a proposed filling station on the feasibility of filling stations in close proximity. The assessment of such impact is necessary in order to minimise the harmful effect of the proliferation of filling stations on the environment. The 
requirement to consider the impact of a proposed development on socio-economic conditions, including the impact on existing developments addresses this concern.

[81] Finally NEMA requires "a risk averse and cautious approach" to be applied by decision-makers. This approach entails taking into account the limitation on present knowledge about the consequences of an environmental decision. This precautionary approach is especially important in the light of section 24(7)(b) of NEMA which requires the cumulative impact of a development on the environmental and socio-economic conditions to be investigated and addressed. An increase in the risk of contamination of underground water and soil, and visual intrusion and light, for example, are some of the significant cumulative impacts that could result from the proliferation of filling stations. Subsection 24(7)(b) specifically requires the investigation of the potential impact, including cumulative effects, of the proposed development on the environment and socio-economic conditions, and the assessment of the significance of that potential impact. ${ }^{30}$

[82] What was required of the environmental authorities therefore was to consider the impact on the environment of the proliferation of filling stations as well as the impact of the proposed filling station on existing ones. This conclusion makes it plain that the obligation to consider the socio-economic impact of a proposed development is wider than the requirement to assess need and desirability under the Ordinance. It also comprehends the obligation to assess the cumulative impact on the environment of the proposed development.

[83] What remains to be considered now is whether the environmental authorities complied with this obligation.

\section{Did the environmental authorities comply with their obligations under NEMA?}

[84] It is common cause that the environmental authorities themselves did not consider need and desirability. They took the view that these were matters that must be "proven, argued and considered by the Local Council" when an application for rezoning is made in terms of section 56 of the Ordinance.

[88] By their own admission therefore the environmental authorities did not consider need and desirability. Instead they relied upon the fact that (a) the property was rezoned for the construction of a filling station; (b) a motivation for need and desirability would have been submitted for the purposes of rezoning; and (c) the town-planning authorities must have considered the motivation prior to approving the rezoning scheme. Neither of environmental authorities claims to have seen the motivation, let alone read its contents. They left the consideration of this vital aspect of their environmental obligation entirely to the local authority. This in my view is manifestly not a proper discharge of their statutory duty. This approach to their obligations, in effect, amounts to unlawful delegation of their duties to the local authority. This they cannot do.

[91] What must be stressed here is that the question on review is not whether there is evidence that an additional filling station posed undue threat to the environment. The question is whether the environmental authorities considered and evaluated the social and economic impact of the proposed filling station on existing ones and how an additional filling station would affect the environment. Indeed it is difficult to fathom how the environmental authorities could have assessed the threat of overtrading to the environment if they did not apply their minds to this question at all. They could have established such threats if they had applied their mind to this question. They did not do so. Their decision cannot therefore stand.

\footnotetext{
${ }^{30}$ Section 24(7)(b) of NEMA provides:

"Procedures for the investigation, assessment and communication of the potential impact of activities must, as a minimum, ensure ... investigation of the potential impact, including cumulative effects, of the activity and its alternatives on the environment, socio-economic conditions and cultural heritage, and assessment of the significance of that potential impact".
} 
[92] It is no answer by the environmental authorities to say that had they themselves considered the need and desirability aspect, this could have led to conflicting decisions between the environmental officials and the town-planning officials. If that is the natural consequence of the discharge of their obligations under the environmental legislation, it is a consequence mandated by the statute. It is impermissible for them to seek to avoid this consequence by delegating their obligations to the townplanning authorities. What is of grave concern here is that the environmental authorities did not even have sight of the motivation placed before the local authority relating to need and desirability, let alone read it. Section 24(1) of NEMA makes it clear that the potential impact on socio-economic conditions must be considered by "the organ of state charged by law with authorising, permitting or otherwise allowing the implementation of [a proposed] activity."

[97] In any event, there is no suggestion that either the town-planning authorities, or the environmental authorities applied their minds to the impact of the proposed filling station on socioeconomic conditions. The scoping report was concerned primarily with the financial feasibility of the proposed filling station. In fact, it said nothing about the impact of the proposed filling station on the existing ones. In all the circumstances of this case, the environmental authorities took a narrow view of their obligations and misconstrued their obligations. As a consequence of this, the environmental authorities failed to apply their minds to the impact of the proposed filling station on socio-economic conditions.

[98] Before concluding this judgment, there are two matters that should be mentioned in relation to the duty of environmental authorities which are a source of concern. The first relates to the attitude of Water Affairs and Forestry and the environmental authorities. The environmental authorities and Water Affairs and Forestry did not seem to take seriously the threat of contamination of underground water supply. The precautionary principle required these authorities to insist on adequate precautionary measures to safeguard against the contamination of underground water. This principle is applicable where, due to unavailable scientific knowledge, there is uncertainty as to the future impact of the proposed development. Water is a precious commodity; it is a natural resource that must be protected for the benefit of present and future generations.

[99] In these circumstances one would have expected that the environmental authorities and Water Affairs and Forestry would conduct a thorough investigation into the possible impact of the installation of petrol tanks in the vicinity of the borehole, in particular, in the light of the existence of other filling stations in the vicinity. The environmental authorities did not consider the cumulative effect of the proliferation of filling stations on the aquifer. The Geohydrology division of Water Affairs and Forestry was content with simply stating that the developer must ensure that there is no pollution of water and that there must be monitoring as proposed in the report and in accordance with the regulations. Neither the Water Quality Management nor the Water Utilization divisions of the Water Affairs and Forestry commented on the reports as they did not receive them. They became aware of the development after both the record of decision and the appeal from it had been issued.

[100] The other matter relates to the attitude of the environmental authorities to the objection of the applicant to the construction of the proposed filling station. In the Supreme Court of Appeal they argued that the applicant's opposition to the application for authorisation was motivated by the desire to stifle competition which was "thinly disguised as a desire to protect the environment". In this regard, they pointed to the fact that the main deponent on behalf of the applicant, Mr Le Roux, owns other filling stations in the area. The Supreme Court of Appeal found that "there appears to be some merit in the contention." Whatever, the merits of the criticism may be, a matter on which it is not necessary to express an opinion, an environmental authority whose duty it is to protect the environment should welcome every opportunity to consider and assess issues that may adversely affect the environment.

[101] Similarly, the duty of a court of law when the decision of an environmental authority is brought on review is to evaluate the soundness or otherwise of the objections raised. In doing so, the court must apply the applicable legal principles. If upon a proper application of the legal principles, the objections are valid, the court has no option but to uphold the objections. That is the duty that is 
imposed on a court by the Constitution, which is to uphold the Constitution and the law which they “... must apply impartially and without fear, favour or prejudice." Neither the identity of the litigant who raises the objection nor the motive is relevant.

[102] The role of the courts is especially important in the context of the protection of the environment and giving effect to the principle of sustainable development. The importance of the protection of the environment cannot be gainsaid. Its protection is vital to the enjoyment of the other rights contained in the Bill of Rights; indeed, it is vital to life itself. It must therefore be protected for the benefit of the present and future generations. The present generation holds the earth in trust for the next generation. This trusteeship position carries with it the responsibility to look after the environment. It is the duty of the court to ensure that this responsibility is carried out. Indeed, the Johannesburg Principles adopted at the Global Judges Symposium underscore the role of the judiciary in the protection of the environment. ${ }^{31}$

[103] On that occasion members of the judiciary across the globe made the following statement-

"We affirm our commitment to the pledge made by world leaders in the Millennium Declaration adopted by the United Nations General Assembly in September 2000 'to spare no effort to free all of humanity, and above all our children and grandchildren, from the threat of living on a planet irredeemably spoilt by human activities, and whose resources would no longer be sufficient for their needs".

In addition, they affirmed-

“... that an independent Judiciary and judicial process is vital for the same implementation, development and enforcement of environmental law, and that members of the Judiciary, as well as those contributing to the judicial process at the national, regional and global levels, are crucial partners for promoting compliance with, and the implementation and the enforcement of, international and national environmental law".

[104] One of these principles expresses-

"A full commitment to contributing towards the realization of the goals of sustainable development through the judicial mandate to implement, develop and enforce the law, and to uphold the Rule of Law and the democratic process ..."

Courts therefore have a crucial role to play in the protection of the environment. When the need arises to intervene in order to protect the environment, they should not hesitate to do so.

\section{Conclusion}

[105] The considerations set out above make it clear that the decision of the environmental authorities is flawed and falls to be set aside as they misconstrued the obligations imposed on them by NEMA. In all the circumstances, the decision by the environmental authorities to grant authorisation for the construction of the filling station under section 22(1) of ECA cannot stand and falls to be reviewed and set aside. It follows that both the High Court and the Supreme Court of Appeal erred, the High Court in dismissing the application for review and the Supreme Court of Appeal in upholding the decision of the High Court.

\section{The relief}

[106] The appropriate relief in this case is to send the matter back to the environmental authorities for them to consider the matter afresh in a manner that is consistent with this judgment.

\section{Costs}

31 United Nations Environment Programme - Division of Policy Development and Law, Global Judges Symposium on Sustainable Development and the Role of Law - The Johannesburg Principles on the Role of Law and Sustainable Development adopted at the Global Judges Symposium held in Johannesburg, South Africa on 18-20 August 2002, http://www.unep.org/dpdl/symposium/Principles.htm, accessed on 4 June 2007. 
[107] Then there is the question of costs. This is a case, in my view, in which the costs should follow the result. However, I do not think that the Trust and its trustees must be saddled with costs. It is true that they opposed the matter - but this was to safeguard their interests. The contest, at the end of the day, was between the applicant and the first, second and third respondents. It is these respondents who should pay the cost of the applicant while the remaining respondents who opposed the matter will have to look after their own costs. The costs payable by the first, second and third respondents must include those that are consequent upon the employment of two counsel.

Moseneke DCJ, Madala J, Mokgoro J, Navsa AJ, Nkabinde J, O'Regan J, Skweyiya J, and Van der Westhuizen $\mathrm{J}$ concur in the judgment of Ngcobo $\mathrm{J}$.

\section{Questions \& Discussion}

1. In Argentina, the right is deemed a subjective right entitling any person to initiate an action for environmental protection. Kattan, Alberto and Others v. National Government, Juzgado Nacional de la Instancia en lo Contenciosoadministrativo Federal. No. 2, Ruling of 10 May 1983, La Ley, 1983D, 576; Irazu Margarita v. Copetro S.A. , Camara Civil y Comercial de la Plata, Ruling of 10 May 1993 (available at www.eldial.com)("The right to live in a healthy and balanced environment is a fundamental attribute of people. Any aggression to the environment ends up becoming a threat to life itself and to the psychological and physical integrity of the person."). See also Asociacion Para la Proteccion de Medio Ambiente y Educacion Ecologica '18 de Octubre'v Aguas Argentinas S.A. \& otros, Federal Appellate Tribunal of La Plata (2003); Kattan, Alberto and Others v. National Government, Juzgado Nacional de la Instancia en lo Contenciosoadministrativo Federal. No. 2, Ruling of 10 May 1983, La Ley, 1983-D, 576. Colombia also recognizes the enforceability of the right to environment. Fundepublico v. Mayor of Bugalagrande and Others, Juzgado Primero superior, Interlocutorio \# 032, Tulua, 19 Dec. 1991 ("It should be recognized that a healthy environment is a sina qua non condition for life itself and that no right could be exercised in a deeply altered environment."). For Chilean cases see Pablo Orrego Silva y Otros v. Empresa Electrica Pange SA (Supreme Court, Aug. 5, 1993); Antonio Horvath Kiss y Otros v. National Commission for the Environment (Supreme Court, March 19, 1997).

2. Is it necessary or useful to include the right to a safe and healthy environment among human rights guarantees? Or is this simply "devaluing the currency" by unnecessarily adding desires and claims to the catalogue of accepted guarantees? The UN General Assembly set forth criteria for adding to the network of international human rights standards in resolution 41/120 (Dec. 4, 1986). The resolution recognized the value of continuing efforts to identify specific areas where further international action is required to develop the existing international legal framework, adding that standard-setting should be effective and efficient and in accord with the following guidelines:

a. Be consistent with existing body of international human rights law;

b. Be of fundamental character and derive from the inherent dignity and worth of the human person;

c. Be sufficiently precise to give rise to identifiable and practicable rights and obligations;

d. Provide, were appropriate, realistic and effective implementation machinery, including reporting systems;

e. Attract broad international support.

Do these guidelines support the further development of the right to a safe and healthy environment?

3. From the above readings, does it seem that the right to environment is widely accepted as a justiciable right? What does it contribute to human rights or to environmental protection?

4. For further reading: Gudmundur Alfredson and Alexandre Ovsiouk, "Human Rights and the Environment," 60 NORDIC J. INT'L L. 19 (1991); L. Collins, "Are We there Yet? The Right to Environment in International and European Law," 2007 MCGILL INT'L J. OF SUSTAINABLE DEVElopMent L \& POL'Y 119; Philippe Cullet, “Definition of an Environmental Right in a Human 
Rights Context," 13 Neth. Q. Hum. RTS. 25 (1995); Maguelonne Dejeant-Pons, "The Right to Environment in Regional Human Rights Systems," in HUMAN RIGHTS IN THE TWENTY-FIRST CENTURY 595 (Paul Mahoney \& Kathleen Mahoney eds., 1993); Maguelonne Dejeant-Pons and Marc Pallemaerts, Droits DE L'Homme ET EnVIRONnEMEnT (2002). Richard Desgagne, "Integrating Environmental Values into the European Convention on Human Rights," 89 AM. J. INT'L L.263 (1995); Malgosia Fitzmaurice, The Right of the Child to a Clean Environment, 23 S. ILL. U. L.J. 611 (1999); Gunther Handl, "Human Rights and Protection of the Environment: A Mildly 'Revisionist' View," in HUMAN Rights AND ENVIRONMENTAL PROTECTION (Antonio A. Cancado Trindade ed., 1992); Human Rights Approaches to Environmental Protection (Alan Boyle \& Michael Anderson eds., 1996); Michael J. Kane, "Promoting Political Rights to Protect the Environment," 18 YAle J. INT'L L. 389. Alexandre Kiss, Le Droit la Conservation de l'environnement, 1 REV. UnIVERSELle DES DROITS DE L'HOMME 445 (1990); John Lee, The Underlying Legal Theory to Support a Well-Defined Human Right to a Healthy Environment as a Principle of Customary International Law, 25 COLUM. J. ENVTL. L.. 283, 308-09 (2000); James T. McClymonds, The Human Right to a Healthy Environment: An International Legal Perspective, 37 N.Y.L.S. L.REV. 583 (1992); Karen E. MacDonald, Sustaining the Environmental Rights of Children: An Exploratory Critique, 18 Fordham ENVTL. L. REV. 1, 39 (2006); Ole Pedersen, European Environmental Human Rights and Environmental Rights: A Long Time Coming? 21 GEO. INT'L ENVT'L L. REV. (2008); Neil Popovic, "In Pursuit of Environmental Human Rights: Commentary on the Draft Declaration of Principles on Human Rights and the Environment," 27 Col. HuM. RTS. REV. 487 (1996); Dinah Shelton, What Happened in Rio to Human Rights? 4 Y.B.INT'L ENVTL. L. 75 (1994); Dinah Shelton, "Environmental Rights," in PEOPLes Rights (Philip Alston ed., 2001); Melissa Thorme, "Establishing Environment as a Human Right," 19 DEN J. INT'L L. \& POL'Y 302 (1991); Jon van Dyke, "A Proposal to Introduce the Right to a Healthy Environment into the European Convention Regime,"13 VA. ENVTL. L. J. 323 (1993).

\section{A Universal Declaration on Human Rights and the Environment?}

In 1994, Fatma Zohra Ksentini, Special Rapporteur of the former Sub-Commission on the Prevention of Discrimination and Protection of Minorities (later called the Sub-Commission for the Promotion and Protection of Human Rights), released a Final Report ("Ksentini Report") examining the relationship between human rights and the environment, excerpted below. One of the most striking conclusions of the Ksentini Report is that there has been a "shift from environmental law to the right to a healthy environment" and that this right is part of existing international law and capable of immediate implementation by existing human rights bodies. The Report elaborates that the right is comprised of a number of elements including the right to life, health, development, public participation, and access to information and judicial remedies. The report contains an Appendix setting out a Draft Declaration of Principles on Human Rights and Environment intended to explicitly elaborate the right to environment and its substantive and procedural components. Consider whether the Draft Declaration is akin to the Universal Declaration. Does it possess the potential for pushing human rights and the environment forward?

\section{Draft Declaration of Principles on Human Rights ANd the EnVIRonMent}

Fatma Zohra Ksentini, Special Rapporteur

U.N. Doc. E/CN.4/Sub.2/1994/9 (1994), Annex

... Reaffirming the universality, indivisibility and interdependence of all human rights, 
Recognizing that sustainable development links the right to development and the right to a secure, healthy and ecologically sound environment,

Recalling the right of peoples to self-determination by virtue of which they have the right freely to determine their political status and to pursue their economic, social and cultural development,

Deeply concerned by the severe human rights consequences of environmental harm caused by poverty, structural adjustment and debt programmes and by international trade and intellectual property regimes,

Convinced that the potential irreversibility of environmental harm gives rise to special responsibility to prevent such harm,

Concerned that human rights violations lead to environmental degradation and that environmental degradation leads to human rights violations,

The following Principles are declared:

\section{Part I}

1. Human rights, an ecologically sound environment, sustainable development and peace are interdependent and indivisible.

2. All persons have the right to a secure, healthy and ecologically sound environment. This right and other human rights, including civil, cultural, economic, political and social rights, are universal, interdependent and indivisible.

3. All persons shall be free from any form of discrimination in regard to actions and decisions that affect the environment.

4. All persons have the right to an environment adequate to meet equitably the needs of present generations and that does not impair the rights of future generations to meet equitably their needs.

\section{Part II}

5. All persons have the right to freedom from pollution, environmental degradation and activities that adversely affect the environment, threaten life, health, livelihood, well-being or sustainable development within, across or outside national boundaries.

6. All persons have the right to protection and preservation of the air, soil, water, sea-ice, flora and fauna, and the essential processes and areas necessary to maintain biological diversity and ecosystems.

7. All persons have the right to the highest attainable standard of health free from environmental being.

8. All persons have the right to safe and healthy food and water adequate to their well-

9. All persons have the right to a safe and healthy working environment.

10. All persons have the right to adequate housing, land tenure and living conditions in a secure, healthy and ecologically sound environment. 
11. All persons have the right not to be evicted from their homes or land for the purpose of, or as a consequence of, decisions or actions affecting the environment, except in emergencies or due to a compelling purpose benefiting society as a whole and not attainable by other means. All persons have the right to participate effectively in decisions and to negotiate concerning their eviction and the right, if evicted, to timely and adequate restitution, compensation and/or appropriate and sufficient accommodation or land.

12. All persons have the right to timely assistance in the event of natural or technological or other human-caused catastrophes.

13. Everyone has the right to benefit equitably from the conservation and sustainable use of nature and natural resources for cultural, ecological, educational, health, livelihood, recreational, spiritual or other purposes. This Includes ecologically sound access to nature. Everyone has the right to preservation of unique sites, consistent with the fundamental rights of persons or groups living in the area.

14. Indigenous peoples have the right to control their lands, territories and natural resources and to maintain their traditional way of life. This includes the right to security in the enjoyment of their means of subsistence. Indigenous peoples have the right to protection against any action or course of conduct that may result in the destruction or degradation of their territories, including land, air, water, sea-ice, wildlife or other resources.

\section{Part III}

15. All persons have the right to information concerning the environment. This includes information, howsoever compiled, on actions and courses of conduct that may affect the environment and information necessary to enable effective public participation in environmental decision-making. The information shall be timely, clear, understandable and available without undue financial burden to the applicant.

16. All persons have the right to hold and express opinions and to disseminate ideas and information regarding the environment.

17. All persons have the right to environmental and human rights education.

18. All persons have the right to active, free, and meaningful participation in planning and decision-making activities and processes that may have an impact on the environment and development. This includes the right to a prior assessment of the environmental, developmental and human rights consequences of proposed actions.

19. All persons have the right to associate freely and peacefully with others for purposes of protecting the environment or the rights of persons affected by environmental harm.

20. All persons have the right to effective remedies and redress in administrative or judicial proceedings for environmental harm or the threat of such harm.

\section{Part IV}

21. All persons, individually and in association with others, have a duty to protect and preserve the environment.

22. All States shall respect and ensure the right to a secure, healthy and ecologically sound environment. Accordingly, they shall adopt the administrative, legislative and other measures necessary to effectively implement the rights in this Declaration. These measures shall aim at the prevention of environmental harm, at the provision of adequate remedies, and at the sustainable use of natural resources and shall include, inter alia, 
* collection and dissemination of information concerning the environment

* prior assessment and control, licensing, regulation or prohibition of activities and substances potentially harmful to the environment;

* public participation in environmental decision-making;

* effective administrative and judicial remedies and redress for environmental harm and the threat of such harm;

* monitoring, management and equitable sharing of natural resources;

* measures to reduce wasteful processes of production and patterns of consumption;

* measures aimed at ensuring that transnational corporations, wherever they operate, carry out their duties of environmental protection, sustainable development and respect for human rights; and

* measures aimed at ensuring that the international organizations and agencies to which they belong observe the rights and duties in this Declaration.

23. States and all other parties shall avoid using the environment as a means of war or inflicting significant, long-term or widespread harm on the environment, and shall respect international law providing protection for the environment in times of armed conflict and cooperate in its further development.

24. All international organizations and agencies shall observe the rights and duties in this Declaration.

\section{Part V}

25. In implementing the rights and duties in this Declaration, special attention shall be given to vulnerable persons and groups.

26. The rights in this Declaration may be subject only to restrictions provided by law and which are necessary to protect public order, health and the fundamental rights and freedoms of others.

27. All persons are entitled to a social and international order in which the rights in this Declaration can be fully realized.

\section{Questions and Discussion}

Benefits of the Declaration of Principles. Given that the Draft Declaration of Principles has not been codified into a binding treaty (and is not likely to be so in the foreseeable future), are there any benefits to the Declaration? Neil Popović, then a lawyer with Sierra Club Legal Defense Fund (now Earthrights), took part in an experts meeting immediately prior to the completion of the Ksentini report. The meeting drafted a document that became the Draft Declaration of Principles above. Popović comments:

... The Draft Declaration reflects a progression from earlier discussions of a "right to environment" to consideration of the manner in which recognized human rights apply to environmental issues. The Draft Declaration is neither the last word nor necessarily the best word on any particular aspect of environmental human rights, but it is the most prominent international instrument in the standard-setting process for environmental human rights. ... 
Neither environmental human rights in general nor the Draft Declaration in particular will save the world. Indeed, recognition of the environmental dimension of human rights does not create new obligations for states or for others. It does call for reassessment of existing obligations, however. Environmental human rights and the Draft Declaration provide a framework for addressing domestic and international environmental problems. They both have the potential to advance protection of human rights and the environment. ...

The value of environmental human rights and the Draft Declaration does not, however, rest exclusively on their legal foundation. Human rights affect official and private conduct in part because of the substantial moral weight they carry. Recognition of social values as "human rights," at least where the recognition reflects genuine and well-considered judgment in a democratic society, erects a moral barrier to the contravention of those values. Even in non-democratic countries . . . governments claim to respect human rights.

The Draft Declaration . . . should provide support for advocates of human rights and environmental protection in legal and other forums. Exposition of the legal underpinnings of the principles in the Draft Declaration should bolster their acceptance and their incorporation into legal regimes. The Draft Declaration can serve as a reference point for national and international systems and as a vehicle for development of a formal, binding international legal instrument that protects environmental human rights.

The Draft Declaration can also serve as a focal point for discussion of environmental human rights and for the development of institutions and procedures to enhance protection of these rights. As consideration of environmental human rights principles progresses and as the principles mature, they should provide an increasing sense of empowerment for the victims of environmental human rights abuses and a corresponding sense of restraint for offending governments, individuals, international organizations, and commercial enterprises.

Neil Popović, In Pursuit of Environmental Human Rights: Commentary on the Draft Declaration of Principles on Human Rights and Environment, 27 Colum. Human Rts L. Rev. 487, 493-97 (1996). 